\title{
Surface Snow, Firn and Ice Core Composition in Polar Areas in Relation to Atmospheric Aerosol and Gas Concentrations: Critical Aspects
}

\author{
Gianni Santachiara, Franco Belosi, Alessia Nicosia, Franco Prodi \\ Institute of Atmospheric Sciences and Climate ISAC, National Research Council, Bologna, Italy \\ Email: G.Santachiara@isac.cnr.it
}

Received 3 November 2015; accepted 11 January 2016; published 14 January 2016

Copyright (C) 2016 by authors and Scientific Research Publishing Inc.

This work is licensed under the Creative Commons Attribution International License (CC BY). http://creativecommons.org/licenses/by/4.0/

(c) (i) Open Access

\section{Abstract}

The paper addresses some of the problems surrounding the relation between ice core chemical signals and atmospheric chemical composition in polar areas. The topic is important as the reconstruction of past climate and past atmospheric chemical composition is based on the assumption that chemical concentrations in the air, snow, firn and ice core are correlated. Ice core interpretation of aerosol is more straightforward than that of reactive gases. The transfer functions of gaseous species strongly interacting with ice are complex and additional field and laboratory experiments are required. Ice core chemical signals depend on the chemical composition of precipitations, which are related to the physics of precipitation formation, the chemical composition of the atmosphere, and post-depositional processes. Published papers reporting data on the chemical composition of snow seldom consider the fact that crystal formation and growth in cloud (rimed or unrimed) or near the ground (clear-sky precipitations), hoar-frost formation and surface riming determine different chemical concentrations, even assuming constant background concentration in the atmosphere. This paper discusses the physical and chemical processes affecting the formation of precipitations in polar areas, and the process of scavenging gases from non-growing and growing crystals. Attention is mainly focused on the processes involving nitrate anion in snow, hoar frost and firn. Knowledge of the chemical relationship between surface snow and atmospheric chemical concentration could be enhanced by considering specific events, such as snow falling from cloud, clear sky precipitation, and surface hoar or riming surface, with simultaneous air sampling. In conclusion, field and laboratory experiments are still required to study the scavenging processes during crystal formation. 


\section{Keywords}

\section{Homogeneous Nucleation, Heterogeneous Nucleation, Transfer Function, Scavenging, Riming}

\section{Introduction}

Ice cores with their entrapped air inclusions provide records of past changes in atmospheric trace gas composition. Knowledge of the link between snow composition and atmospheric pollutants presented at the time of deposition (aerosol and gas) should serve to reconstruct past atmospheric conditions. Ice core chemical signals depend on the chemical composition of precipitations and the post-depositional processes on the surface snow and inside the ice core. The extent of knowledge on the air-snow transfer function depends on whether the species of interest are gaseous or in the condensed phase, and if they are reversible and/or irreversibly deposited to snow. A priori, this function may vary from one site to another, from one component to another, or according to metereological conditions.

Non-reactive aerosols (e.g. sea-salt, soil dust, sulphur and carbonaceous species) are irreversibly trapped in snow [1]. Gaseous species have a more complex behaviour than non-reactive aerosols. A few of them, such as methane and carbon dioxide, do not chemically interact with ice, and their past concentrations have been reconstructed by analysing air bubbles trapped in ice cores. Gas concentrations are correlated with climate change deduced from the isotopic composition of the ice core [2] [3]. However, most gases, such as $\mathrm{HCl}, \mathrm{HNO}_{3}, \mathrm{H}_{2} \mathrm{O}_{2}$, and HCHO, interact with ice and these interactions make their transfer function complex [4].

The chemical composition of precipitations depends on atmospheric trace components (gases and aerosol) and in-cloud and below-cloud scavenging processes. In cloud scavenging is related on how hydrometeors (ice crystals, snow, droplets) are formed. This topic is seldom discussed in published papers addressing the relationship between gas and aerosol concentrations in the atmosphere and snow in remote regions [5]-[8]. Numerous reconstructions of past atmospheric composition have been made assuming that atmospheric signals are representative and are transferred to and preserved in snow [9] [10]. Previous discussions on precipitation scavenging in the polar regions have supposed that the processes of aerosol removal are dominated by uptake of the aerosol population as condensation or ice nuclei. For this process, Junge [11] showed that the concentration of a given element in air should be proportional to its concentration in snowfall. Shaw [12] examined the size distribution and vertical variation of the total aerosol over the Antarctic ice sheet and calculated that the removal of particles by nucleation of ice crystals constituted $90 \%$ of the downward particle flux to the surface over the polar ice sheet. Albeit crude and mainly derived from averaged samples, earlier experimental studies on polar ice sheets [13] [14] supported Junge's predictions. However, additional improvements in the chemical analysis and/or interpretation of the results concerning snow and ice have cast doubt on much of the earlier data on Antarctic snow and air composition on which the earlier comparisons are based [10] [15].

Several procedures have been adopted to analyse the relationship between the chemical composition of aerosol and snow. Sometimes simultaneous samples of aerosol and snow were collected [8]-[10] [16] [17], at others fresh snow and aerosol were not synchronically sampled [6] [18].

The results obtained comparing the chemical composition of aerosol and fresh snow have frequently been contradictory, i.e. concentrations in snow and in air are sometimes related and sometimes not [7] [9] [16] [17] [19] [20]. Published papers frequently compared ion concentration (soluble and/or insoluble) in snow and aerosol, neglecting to discuss the fact that snow could also scavenge chemical compounds in the gas phase. Therefore, field campaigns designed to measure scavenging coefficients should sample aerosol, gases and fresh snow simultaneously. Even the few measurements showing that signals recorded in snow reflect changes observed in the atmosphere [21]-[23] cannot be generalized as the results are, strictly speaking, specific to the event considered.

Some models developed for the exchange of energy and chemicals between air and snow [24]-[28]. Dominé et al. [1] attempted to reconstruct past polar atmospheric $\mathrm{HCl}$ mixing ratios from ice core analysis concluding that the transfer function could not be described by equilibrium thermodynamics. The transfer of $\mathrm{HCl}$ (like gaseous water soluble compounds) involves multiple processes and therefore our understanding of the transfer function is incomplete. For compounds that are mostly in the aerosol phase (e.g. $\mathrm{H}_{2} \mathrm{SO}_{4}$ ), the number of processes in- 
volved is smaller, and the difficulties therefore fewer. This paper addresses some of the problems responsible for the complex relationship between ice core chemical signals and atmospheric chemical composition of gases and aerosols in polar areas.

\section{Formation of Precipitations in Polar Areas}

\subsection{Physical and Chemical Processes}

Clouds and precipitations play a fundamental role in the removal of atmospheric particles and gases. Wet removal of pollutants (aerosol and gas) from the atmosphere comprises in-cloud and below-cloud scavenging. In-cloud scavenging of aerosol includes contributions from both nucleation and impaction scavenging (inertial impaction, Brownian diffusion, thermophoresis, diffusiophoresis, and electrostatic effects), while below-cloud scavenging includes only impaction.

Precipitations in polar regions are prevalently solid and can form in different ways (Figure 1). Pristine small ice crystals can derive from homogeneous nucleation of super-cooled droplets or heterogeneous nucleation (deposition, condensation, contact and immersion freezing). Ice crystals can subsequently grow through water vapour diffusion, impaction and freezing of super-cooled droplets (riming) and from crystal aggregation.

The riming process becomes efficient only if droplet diameter is larger than $10 \mu \mathrm{m}$ and crystal diameter is greater than about 50,150 and $300 \mu \mathrm{m}$, when considering dendrites, hexagonal plates and columns, respectively [29] [30]. Riming is likely to be common during the relatively warm summer season in coastal areas of Antarctica, whereas at the South Pole where temperatures are lower, riming is less likely, i.e. the only growth process is water vapour diffusion [31]-[35].

Warburton and Linkletter [36] observed that the relative proportion of accretional and diffusional growth found in ice crystals and snowflakes falling to the surface in Antarctica varied with location. At stations near the coast a significantly high proportion of crystals grown by accretion of supercooled droplets (riming) was observed, whereas at the South Pole growth was almost entirely by diffusion. Microphysical observations of cloud parameters in the Antarctic show predominantly ice crystal clouds across the interior, with mixed-phase clouds close to the coast [37]. In the Arctic (northern coast of Alaska), Mossop et al. [38] and Jayaweera and Ohtake [39] investigated the microphysical characteristics of arctic stratus clouds, observing no riming process in these clouds. Instead, Asuma et al. [40] observed both densely rimed dendrites and graupels in the western Canadian Arctic together with crystals grown by diffusion (plates, columns, bullet rosettes). These two different growth

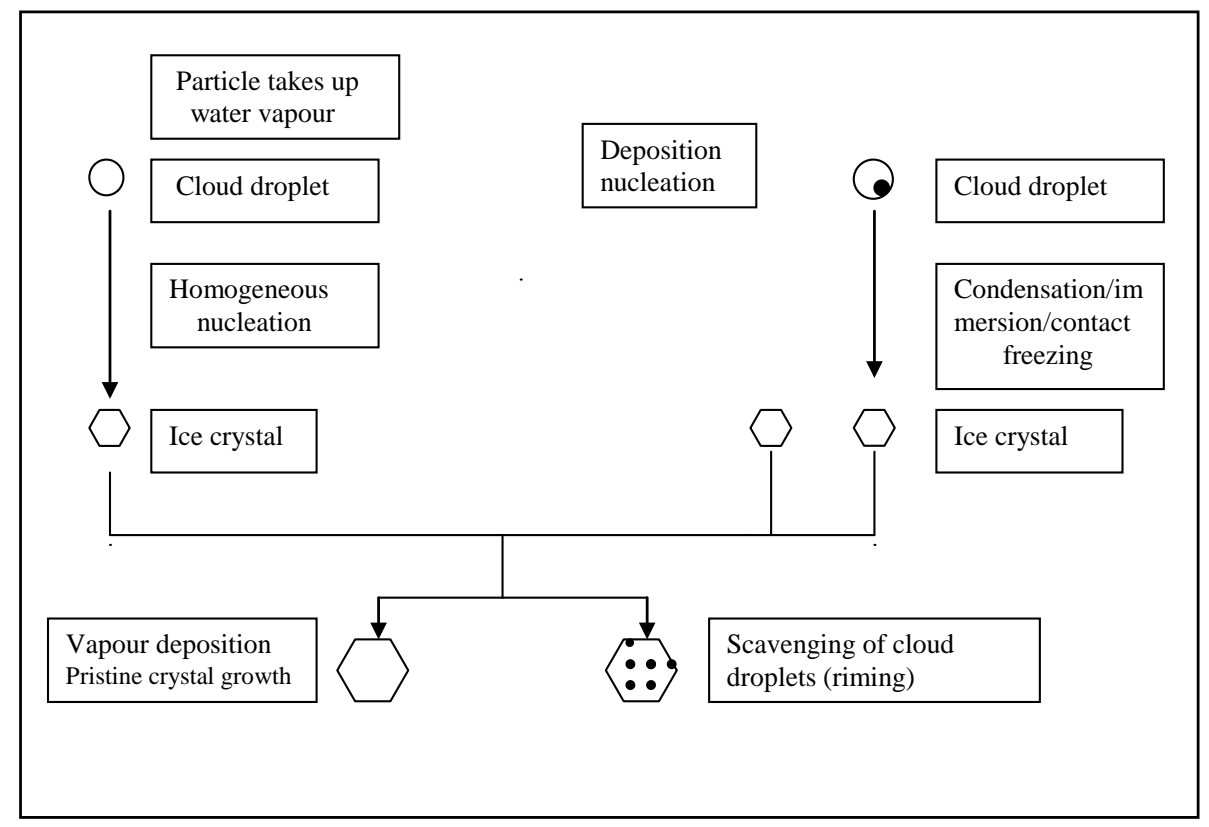

Figure 1. The main processes influencing the chemical composition of snow crystals in Antarctic cloud. 
processes influence the amounts and composition of impurities incorporated into hydrometeors and hence in the polar ice sheets.

Few papers on polar areas have reported the concentrations of pollutants considering the different kinds of precipitations separately. For instance, Douglas et al. [41] collected snow and ice crystals in the air, on the ground and on sea-ice in Alaska to study the deposition of mercury, predominantly present in the atmosphere as a gaseous element. Their results showed that mercury concentrations were related to the type and formation of snow and ice crystals. The concentration of mercury decreased from rime, diamond dust (clear sky precipitations) and surface hoar.

\subsection{Gas Scavenging}

Considering gas scavenging, the main gases present in the Antarctic atmosphere $\left(\mathrm{SO}_{2}, \mathrm{HCl}, \mathrm{HNO}_{3}, \mathrm{NH}_{3}\right)$ are highly soluble in water, and therefore in liquid or mixed clouds they are mainly partitioned into supercooled water droplets. The transfer function of such water-soluble trace gases depends on their fate during freezing, which can be split into: 1) non-rime freezing (homogeneous or heterogeneous nucleation) and 2) riming freezing (aggregation of supercooled water droplets with ice hydrometeors). As gases are less soluble in ice than in water, freezing leads to their exclusion from the forming ice. The subsequent increase in gas concentration in the unfrozen fraction water can eventually determine an outgassing to the atmosphere. The overall process is quantified by the retention coefficient, which is the ratio of the solute mass in the hydrometeors after freezing to the mass originally dissolved in the unfrozen droplets. Measured retention coefficients for gases range from 0.01 to 1 and the values depend on the characteristics and concentration of solutes, droplet sizes, riming conditions (dry or wet) and droplet supercooling. Values increase by raising the effective Henry's constant, i.e. for dissociated soluble gas both in the case of non-rime and riming freezing [42].

Published papers report discrepancies in gas retention coefficient values. For $\mathrm{SO}_{2}$, Lamb and Blumenstein [43] used droplets in the range of a few to $10 \mu \mathrm{m}$, measuring an entrapped fraction that was strongly temperature dependent and varied from about 0.01 near $0^{\circ} \mathrm{C}$ to more than 0.12 at $-20^{\circ} \mathrm{C}$. Iribarne et al. [44] reported an average value of 0.62 , regardless of temperature and $\mathrm{SO}_{2}$ gas phase concentration, for drops ranging from 5 to $40 \mu \mathrm{m}$. Santachiara et al. [45] (1992) showed that gaseous entrapment is greater the higher the freezing rate and increases the lower the $\mathrm{SO}_{2}$ gas concentration.

For $\mathrm{HCl}, \mathrm{HNO}_{3}$ and $\mathrm{NH}_{3}$, the retention coefficients measured in laboratory and in-cloud field campaigns are almost unitary [46]-[49]. Field measurements of hydrogen peroxide suggest values from 0.05 [50] to 0.24 [51], widely different from those reported in the laboratory experiments of Iribarne and Pyshnov [46], and Blohn et al. [49] who measured a unitary and 0.64 retention coefficient, respectively. Values of $\mathrm{pH}$, temperature, and drop size varied between and within the studies. In addition to droplet partitioning during freezing, the interaction of trace gases with the ice surface must be considered in order to evaluate the transfer of gases from air to hydrometeors. The interaction of gases with ice is a complex problem and needs to be addressed to reconstruct past atmospheric concentration from ice core analyses.

Here we summarize the main points. By considering non-growing crystals, the trace gases/ice surface interaction occurs through adsorption and diffusion into the bulk crystal. Thermodynamic equilibrium between gas and ice in the adsorption process develops over long time-scales as diffusion coefficients in solids are very small. For instance, the diffusion coefficient of $\mathrm{HCl}$ at T $=258 \mathrm{~K}$ is about $10-12 \mathrm{~cm}^{2} \cdot \mathrm{s}^{-1}$, while that of $\mathrm{HNO}_{3}$ is higher by a factor of about 100 [52]. In addition, $\mathrm{HNO}_{3}$ is about 25 times less soluble in ice than $\mathrm{HCl}$. Therefore, surface adsorption is valid in the atmospheric processes, while diffusion in the bulk should be negligible. For instance, the migration distance of $\mathrm{NO}_{3}^{-}$in ice should be about $0.8 \mathrm{~cm}$ after 1000 years [53].

Laboratory experiments performed in conditions of growing and non-growing crystals in the presence of $\mathrm{SO}_{2}$, $\mathrm{HNO}_{3}, \mathrm{HCl}, \mathrm{NH}_{3}$ show that gas uptake is higher in the condition of growth [47] [54]-[58]. Hoog et al. [59] showed that non-growing crystals had an $\mathrm{NH}_{3}$ uptake approximately one order of magnitude lower than growing crystals. Published papers prevalently show that crystal uptake of gases increases with the rising gas concentration in air and depends on temperature.

Considering growing ice, several possible mechanisms for the sorption of gases should be considered including surface adsorption and diffusion in the bulk forming a solid solution, co-condensation of gaseous species (i.e. simultaneous condensation of trace gases and water vapour on the ice surface), and dissolution into the quasi-liquid layer (QLL). The impact of QLL should increase by raising the temperature [60]. Abbatt et al. [61] 
measured an enhanced uptake for benzene and acetone at high temperature. QLL thickness strongly depends on temperature and the ionic content of ice [62]-[64]. If crystal growth is due to a diffusion process, the mass flux density of the water vapour and trace gases does not depend only on their gradients, but also on a convective or macroscopic flow, known as Stefan flow [65]-[67].

\section{$\mathrm{HNO}_{3}$ Scavenging}

We will focus on the scavenging processes involving $\mathrm{NO}_{3}^{-}$(particulate and gaseous) as nitrate is the final product of the oxidation of nitrogen oxides $\left(\mathrm{NO}_{\mathrm{x}}=\mathrm{NO}+\mathrm{NO}_{2}\right)$ in the atmosphere and one of the anions dominating the chemical composition of the polar snowpack. The NOx cycle is strongly coupled with $\mathrm{OH}$ and $\mathrm{O}_{3}$ chemistry in the atmosphere [68]. Wet and dry deposition of nitrate (as $\mathrm{HNO}_{3}$ or $\mathrm{NO}_{3}^{-}$) is a sink for $\mathrm{NO}_{\mathrm{x}}$.

By considering the behaviour of nitric acid in the case of non-growing ice, laboratory experiments disclosed a largely irreversible uptake of molecules on a short time-scale [56] [69]-[71]. The results, interpreted as ice surface adsorption, are related to the ability of cirrus clouds to scavenge gas-phase $\mathrm{HNO}_{3}$ in the free troposphere. For diffusionally growing ice crystals, laboratory studies indicate a significantly enhanced uptake of nitric acid compared to experiments with an ice film at equilibrium. The uptake is substantially higher than the thermodynamic solubility limit that is established over long time-scales by diffusion and solubility of $\mathrm{HNO}_{3}$ in bulk ice [53]. Therefore, the uptake of nitric acid molecules on growing ice surfaces leads to more efficient uptake than a pure adsorption and diffusion process [56] [58] [72] [73]. Several uptake mechanisms were considered in published papers, depending on temperature and $\mathrm{HNO}_{3}$ partial pressure, adsorption onto the surface and formation of a monolayer or multilayer of $\mathrm{HNO}_{3}$ molecules on the ice surface, or co-deposition with water vapour in the growing crystal [1] [74]. If the snow crystal has a disordered surface layer (liquid-like layer or premelted layer), $\mathrm{HNO}_{3}$ may partition from the gas-phase into the aqueous surface region, governed by an appropriate Henry's law equilibrium [75]. Under low-temperature conditions and high partial pressure of $\mathrm{HNO}_{3}$, the ice surface can melt due to melting point depression and a supercooled liquid solution is formed. This solution layer should not be confused with the thin liquid-like layer that exists on the surface of pure ice. In this condition a large uptake of $\mathrm{HNO}_{3}$ can occur. For this reason, the various interactions of $\mathrm{HNO}_{3}$ with ice must be studied to reconstruct past atmospheric $\mathrm{HNO}_{3}$ concentrations from ice core analyses.

Zondlo et al. [74] observed two different $\mathrm{HNO}_{3}$ uptake regimes. For $\mathrm{H}_{2} \mathrm{O} / \mathrm{HNO}_{3}$ partial pressure below the supercooled $\mathrm{H}_{2} \mathrm{O} / \mathrm{HNO}_{3}$ liquid isotherm, a time-dependent uptake of $\mathrm{HNO}_{3}$ was observed until the $\mathrm{HNO}_{3}$ surface coverage reached one monolayer. By contrast, when $\mathrm{H}_{2} \mathrm{O}$ and $\mathrm{HNO}_{3}$ partial pressures were greater than the supercooled $\mathrm{H}_{2} \mathrm{O} / \mathrm{HNO}_{3}$ liquid isotherm, a continuous growth was observed. Dominé and Thibert [52] suggested that $\mathrm{HNO}_{3}$ is incorporated in ice growing by deposition of layers of a given thickness whose composition is determined by condensation kinetics. Solid diffusion is not a viable explanation for the large uptake of $\mathrm{HNO}_{3}$, due to its low diffusion coefficient and solubility in ice [69].

By considering $\mathrm{HNO}_{3}$ concentration in sampled snow, a high uptake of gaseous $\mathrm{HNO}_{3}$ in deposited snow sampled at high altitude has been confirmed by experimental field measurements all over the world [5] [6] [9] [24] [76]-[81]. Puxbaum and Tscherwenka [82] collected snow and rime samples at the Sonnblick Observatory (3106 $\mathrm{m}$ a.s.l) estimating that more than $35 \%$ of $\mathrm{NO}_{3}^{-}$in fallen snow came from direct-gas phase scavenging by ice crystals. Mitchell and Lamb [83], Mitchell and Borys [84], and Duncan [85] found comparable values of $\mathrm{NO}_{3}^{-}$in rimed and unrimed snow. Field measurements disclosed a weak correlation between nitrate in aerosol and snow [5] [6] [80] and a positive correlation for $\mathrm{NO}_{3}^{-}$in fresh snow, and the sum of $\mathrm{HNO}_{3}$ and nitrate in air [5] [8] [86].

\section{The Post-Depositional Process}

Many post-depositional processes affect the composition of glacial ice. Figure 2 shows some of the post-depositional processes, co-condensation of water vapour and gases with formation of hoar frost on the ice surface, formation of rime on the snow surface during fog episodes, adsorption/desorption of gases, diffusion through the snow/firn layer, an advective process due to wind-pumping, sublimation of snow, volatilization of chemical species, snow grain metamorphism within the pack, chemical and photochemical reactions in snow, and dry deposition. These processes affect and continuously alter the chemical composition of the snow surface, firn, and ice core, and therefore the actual air-to-snow transfer function. Diurnal variations of meteorological parameters (e.g. temperature, water vapour partial pressure, intensity of solar radiation) are closely linked to these processes [87]. 


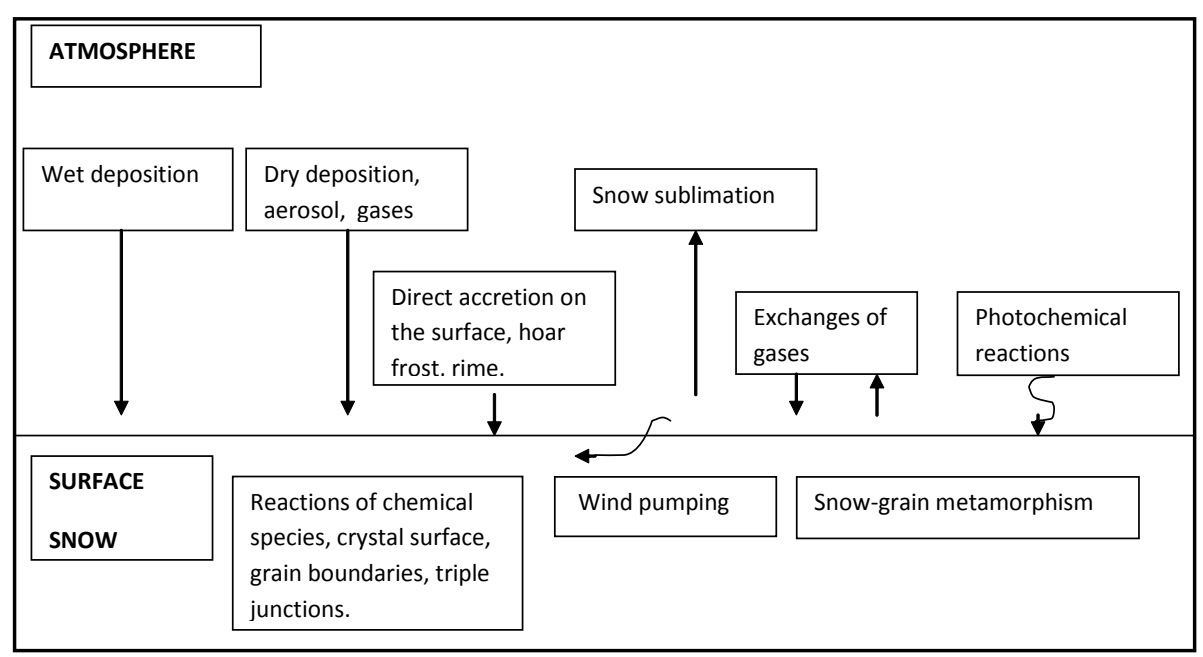

Figure 2. Scheme of post-depositional processes (adapted from Tranter and Jones [88]).

Dry deposition occurs continuously by sedimentation, diffusion, and impaction of particles on the snow surface [89]. Strong temperature inversions can favour deposition due to thermophoresis. The contribution of dry deposition in Antarctica is higher during winter (due to the lower precipitation rate and decreased scavenging efficiency of unrimed snow in winter), and on sites in central Antarctica, which have very low snow accumulation rates with respect to coastal regions [90] [91]. According to Gjessing [92], dry deposition is the dominant sink on the Antarctic Plateau, whereas snow scavenging predominates in the coastal areas of Antarctica [16].

Hoar on snow can form by the deposition of atmospheric vapour water when its surface cools radiatively in the absence of strong winds. Hoar can form even during the day around noon, when the upward flux of water vapour from the warmer snowpack condenses at snowpack surface.

Post-depositional processes include adsorption and desorption of gases from the snow surface. Laboratory results on the adsorption-desorption of gases (e.g. $\mathrm{HCl}, \mathrm{HNO}_{3}, \mathrm{SO}_{2}, \mathrm{NH}_{3}, \mathrm{H}_{2} \mathrm{O}_{2}, \mathrm{HCHO}, \mathrm{HONO}$ ) from non-growing crystals can be assumed to be valid even for surface snow in stationary conditions [1] [55] [56] [59] [93]-[96]. Prevalently laboratory results showed a gas uptake decreasing at lower temperatures and a maximum uptake at temperatures near $0^{\circ} \mathrm{C}$, due to the presence of a quasi-liquid layer on the grain surface.

Gases can influence each other during uptake. Runs made with $\mathrm{NH}_{3}$ in the presence of $\mathrm{SO}_{2}$ yielded higher concentrations in the ice phase than did runs made with single gases [57] [59]; likewise, $\mathrm{SO}_{2}$ in the presence of oxidants [96]. Co-adsorption of $\mathrm{HCl}$ and $\mathrm{HNO}_{3}$ shows that $\mathrm{HNO}_{3}$ adsorbs more strongly than $\mathrm{HCl}$, and that $\mathrm{HCl}$ is displaced from the ice surface as a result of acidification by $\mathrm{HNO}_{3}$ [70]. The presence of an acidic surface (e.g. by the presence of sulphuric acid) can inhibit the uptake of nitric acid [97]. Sublimation of water vapour from the snow surface of non-volatile compounds can determine an increase in chemical concentration in surface snow records. This could be misinterpreted as dry deposition [98].

Metamorphic processes, i.e. changes in the shapes and sizes of snow grains, occur in deposited snow. Grain coarsening was observed in stratigraphy performed by Gow [99] at the South Pole. Snow ageing reduces the surface free energy as grain growth and the surface area decreases, thereby decreasing the potential for surface storage. Metamorphism also affects macroscopic physical properties such as density, thermal conductivity and albedo [100]-[102]. A decrease of the snow surface area will result in the emission of trace gases from the snow surface [103]. Physiochemical and photochemical processes in the snow pack occur for a variety of important chemical species. Surface snow is a porous medium with a high surface area and low density (in the range 0.01 to $0.2 \mathrm{~g} \cdot \mathrm{cm}^{-3}$ ), and therefore consists prevalently of air. Light can penetrate the surface and the photochemical activity releases gases into the atmosphere $\left(\mathrm{NO}_{\mathrm{x}}, \mathrm{H}_{2} \mathrm{O}_{2}\right.$, $\mathrm{HCHO}$, organic acid, halogens, etc.). Many studies have observed significant changes in the concentration of gases contained in the deposited snow due to metamorphism, photolysis, diffusion out of the snow crystals, etc. [104]-[106] In addition, the distribution of impurities between the different domains of the condensed phase inside the snowpack (at the grain surface, in the bulk of the solid, in liquid trapped in confined pockets between grains), the presence of a multiphase system where liquid solutions and ice coexist, and changes in snow structure and properties affect both physical processes and 
chemical reactivity [107].

\section{Nitrate in Snow, Hoar Surface Crystals and Firn}

Nitrate has been measured extensively in ice cores, and advocated as a proxy for a host of different parameters (e.g. lightning frequency, past solar activity, stratospheric temperature). The study of polar ice cores can provide information on sources of $\mathrm{NO}_{\mathrm{x}}$ (e.g. surface, tropospheric, middle atmospheric sources). Nitrate has traditionally been assumed to be oxidized irreversibly in the atmosphere, and therefore nitrate concentration profiles in ice cores have long been thought to preserve information on atmospheric $\mathrm{NO}_{\mathrm{x}}$ concentrations. However, more recent studies [108]-[110] indicate that the snowpack is reactivating $\mathrm{NO}_{3}^{-}$, and it is now acknowledged that its deposition is reversible. Therefore, the link between the atmospheric concentration of $\mathrm{NO}_{\mathrm{x}}$ and $\mathrm{NO}_{3}^{-}$in the ice core is particularly problematic.

Udisti et al. [7] collected atmospheric aerosol, superficial snow layers and firn samples from snow pits at Dome Concordia station during the 2000/2001 summer field season. Comparative analysis of aerosol, surface hoar and surface snow showed differences in chemical composition. Nitrate and chloride exhibited higher concentrations in the surface hoar with respect to snow samples, and low concentrations were measured in the aerosol. Udisti et al.'s results (2004) demonstrate that nitrate and chloride are mainly in the gas phase at Dome C and can be captured by the snow and hoar surface through dry deposition and adsorption. However, the wet deposition process in polar regions includes precipitations from clouds, clear-sky precipitations, formation of surface hoar frost (prevalently during night-time), and surface deposition of freezing droplets (rime). Therefore, the difference between nitrate/chloride concentrations in hoar frost and snow could also depend on: 1) different scavenging mechanisms for precipitating crystals from clouds and crystals forming near the surface, and 2) a different near-surface gas/aerosol concentration with respect to cloud. An additional interpretation of the high concentrations in "hoar samples" could be the presence of small rime droplets due to fog deposition, highly concentrated in $\mathrm{HNO}_{3}$ almost completely retained during freezing [91].

During a campaign carried out at Dome C (January 2009-January 2010), Erbland et al. [111] compared the particulate nitrate and gaseous $\mathrm{HNO}_{3}$ in the atmosphere with the nitrate concentration of surface snow samples (referred to as the "skin layer") collected every three days. $\mathrm{NO}_{3}^{-}$mass fractions in skin layer snow exhibited a seasonal pattern similar to that observed for the atmosphere, but temporal variations of $\mathrm{NO}_{3}^{-}$mass in the skin layer were offset from those observed in the atmosphere by a period of about three to four weeks. In our opinion, the paper suffers from the lack of information on the wet deposition (clouds or cloudless precipitation, hoar formation, surface riming) during the atmospheric and snow samplings in order to explain the results.

Neubauer and Heumann [112] [113] found much higher nitrate concentrations in hoar frost (548 $\mathrm{ng} \cdot \mathrm{g}^{-1}$ ) with respect to fresh snow and firn cores (206 ng.g ${ }^{-1}$ and $61 \mathrm{ng} \cdot \mathrm{g}^{-1}$, respectively) in samples collected at the German Antarctic station "Georg-von-Neumayer" (January and February 1987). As snow was collected a few hours after snowfall, the higher concentration in surface hoar should not depend on a photochemistry loss in snow.

Champollion et al. [114] investigated hoar evolution through continuous observations of the surface by in situ near-infrared photography and passive microwave remote sensing at Dome C. Observations during 18 months even during the polar winter (when the air and snow temperatures are low and air contains very little water vapour) demonstrated that hoar is far from a marginal phenomenon at Dome C. Hoar is present on the surface almost half of the time all year round, and the hoar periods are usually longer in summer than in winter. According to the authors, the nature of these crystals is either "surface hoar" formed by condensation of the air water vapour onto the surface during the night, or frost flower-like crystals formed by upwelling vapour emanating from the snow a few centimetres under the surface in daytime. Linkletter and Warburton [115] reported measurements performed at Ross Ice Shelf, which revealed rime and hoar for about $10 \%$ of days in the period October-March.

Due to high frequency of hoar formation in the Antarctic plateau, laboratory and field experiments should be performed to study the scavenging process during the formation of crystals on the snow surface. In addition, surface "hoar" crystals should be sampled carefully, by also performing an optical observation to verify if the crystals are unrimed or rimed, i.e. whether they contain spherical microdroplets and microcrystals arising from the freezing of fog droplets. To further highlight the need to take the physics of hydrometeor formation into account to explain snow nitrate concentration, we recall the paper by Wolff et al. [116] who observed nitrate concentration spikes from day to day in surface snow at Halley (Antarctica), and stated that they could depend on 
scavenging of fluctuating nitrate concentrations in cloud.

The importance of the physics of precipitation formation processes in determining the chemical composition of the polar snowpack is a general issue, not confined to nitrate. Several papers report a large decrease of $\mathrm{NO}_{3}^{-}$ within the top metre in low accumulation areas, such as Dome C or Vostok on the East Antarctic Plateau [116][121]. Lower temperature and higher nss- $\mathrm{Ca}_{2}^{+}$should reduce $\mathrm{NO}_{3}^{-}$loss despite lower accumulation rates [122]. On the other hand, high accumulation sites (e.g. Summit, Greenland) currently preserve more than $90 \%$ of the initial $\mathrm{NO}_{3}^{-}$[123]. Generally speaking, the relationship between accumulation rate and nitrate concentration is complex as the connection between temperature, elevation, accumulation rate and snow $\mathrm{pH}$ at the time of deposition makes it difficult to distinguish between the separate effects [122].

In order to enhance our understanding of the sources of nitrate found in the ice core and try to reconstruct past atmospheric composition, the nitrogen isotope composition $\left[\delta^{15} \mathrm{~N}\right]$ of $\mathrm{NO}_{3}^{-}$is considered. The parameter is defined as,

$$
\left[\delta^{15} \mathrm{~N}\right](\%)=[(\mathrm{Rspl} / \text { Rref })-1] \times 1000
$$

$\mathrm{R}$ is the elemental isotope ratio $15 \mathrm{~N} / 14 \mathrm{~N}$ in sample and standard, respectively. Atmospheric nitrogen $\left(\mathrm{N}_{2}\right)$ has been established as the international reference for $15 \mathrm{~N} / 14 \mathrm{~N}$.

In the ice core, $\left[\delta^{15} \mathrm{~N}\right]$ depends on $\mathrm{NO}_{\mathrm{x}}$ sources and post-depositional process. Lack of available data on the $\left[\delta^{15} \mathrm{~N}\right]$ of $\mathrm{NO}_{\mathrm{x}}$ sources (lightning, biomass burning, biogenic processes in soils, fossil fuel combustions, oxidation of ammonia) is a limiting factor [124]. The physical release of $\mathrm{HNO}_{3}$ and $\mathrm{NO}_{3}^{-}$photolysis in the UV range has been proposed to explain nitrate loss from snow. The relative importance of the photochemical and physical loss processes at a given site is a key issue to improve the interpretation of the nitrate ice core and determine the nitrate transfer function at the air-snow interface. This requires a knowledge of the nitrogen isotopic fractionation constant associated with each loss process [111].

Photolytic fractionation of nitrate in natural snow was studied in a series of experiments by Berhanu et al. [125] and resulted in significant nitrogen isotopic fractionation that is strongly dependent on the wavelength spectrum of irradiation. At Dome C, photolysis should dominate nitrate loss [111] [121]. Field studies in the Antarctic as well as laboratory experiments have shown that the photochemical reduction of nitrates takes place in the superficial liquid-like layer of snow [126] [127]. This should explain the lower concentration of $\mathrm{NO}_{3}^{-}$in sites with low snow accumulation rates.

\section{Conclusions}

The relation between the concentrations of ionic substances in precipitating snow and those of their precursors in the air depends largely on the particular mix of scavenging processes active at the time of snow formation (growing crystals, non-growing crystals, rimed or unrimed crystals, dry or wet riming) and during precipitation falling.

Precipitations in polar areas are prevalently in the solid phase. The pristine small ice crystals derived from homogeneous nucleation of super-cooled droplets or heterogeneous nucleation subsequently grow by water vapour diffusion, impaction and freezing of supercooled droplets (riming) and crystal aggregation. Gases and particles are scavenged during in-cloud processes and hydrometeor falling. In addition to hydrometeors formed in cloud, wet deposition includes further processes, i.e. clear-sky precipitations, formation of surface hoar frost (prevalently during night-time), and surface deposition of freezing droplets (rime).

The scavenging efficiency of gases and aerosol differs for each of the above-cited processes. Therefore, even assuming an approximately constant "background" chemical concentration in the atmosphere, the concentration in the deposit should vary with the physics of precipitation formation and the deposition process. This topic is seldom discussed in published papers addressing the relationship between precipitation chemistry and atmospheric chemical composition of gases and aerosols in remote regions.

After carbon dioxide and methane, nitrate (the final product of the oxidation of nitrogen oxides) is the main chemical compound on which researches focus to try to reconstruct past levels of atmospheric nitrogen dioxide from the ice core. In addition to the scavenging processes in the atmosphere, attention must be paid to post-depositional processes which alter nitrate concentration and isotopic composition in deposited snow. The diffusive growth of crystals is prevalent in polar regions due to the high frequency of hoar formation, clear precipitation events, and low frequency of riming process in cloud. 
Therefore, additional laboratory and field experiments are required to study the scavenging process during crystal formation, and samplings in field campaigns should be carefully performed for a separate analysis of snow precipitations, cloudless ice crystal precipitation, hoar formation, and surface riming.

\section{References}

[1] Dominé, F., Thibert, E., Silvente, E., Legrand, M. and Jaffrezo, J-L. (1995) Determining Past Atmospheric HCl Mixing Ratios from Ice Core Analyses. Journal of Atmospheric Chemistry, 21, 165-186. http://dx.doi.org/10.1007/BF00696579

[2] Chappellaz, J., Barnola, J.-M., Raynaud, D., Korotkevich, Y.S. and Lorius, C. (1990) Ice-Core Record of Atmospheric Methane over the Past 1600,000 Years. Nature, 345, 127-131. http://dx.doi.org/10.1038/345127a0

[3] Petit, J.R., Jouzel, J., Raynaud, D., Barkov, N.I., Barnola, J.-M., Basile, I., Benders, M., Chappellaz, J., Davis, M., Delaygue, G., Delmotte, M., Kotlyakov, V.M., Legrand, M., Lipenkov, V.Y., Lorius, C., Pépin, L., Ritz, C., Saltzman, E. and Stievenard, M. (1999) Climate and Atmospheric History of the Past 420,000 Years from the Vostok Ice Core, Antarctica. Nature, 399, 429-436. http://dx.doi.org/10.1038/20859

[4] Legrand, M. (1995). Ice Core Chemistry, Implications for Our Past Atmosphere. In: Moorgaat, G., et al., Eds., NATO ASI, Low-Temperature Chemistry of the Atmosphere, Springer-Verlag, Berlin, 421-445.

[5] Toom-Sauntry, D. and Barrie, L.A. (2002) Chemical Composition of Snowfall in the High Arctic, 1990-1994. Atmospheric Environment, 36, 2683-2693. http://dx.doi.org/10.1016/S1352-2310(02)00115-2

[6] Shrestha, A.B., Wake, C.P., Dibb, J.E. and Whitlow, S.I. (2002) Aerosol and Precipitation Chemistry at a Remote Himalayan Site in Nepal. Aerosol Science and Technology, 36, 441-456. http://dx.doi.org/10.1080/027868202753571269

[7] Udisti, R., Becagli, S., Benassai, S., Castellano, E., Fattori, I., Innocenti, M., Migliori, A. and Traversi, R. (2004) Atmosphere-Snow Interaction by a Comparison between Aerosol and Uppermost Snow-Layers Composition at Dome C, East Antarctica. Annals of Glaciology, 39, 1-9. http://dx.doi.org/10.3189/172756404781814474

[8] Yalcin, K., Wake, C.P., Dibb, J.E. and Whitlow, S.I. (2006) Relationships between Aerosol and Snow Chemistry at King Col, Mt. Logan Massif, Yukon, Canada. Atmospheric Environment, 40, 7152-7163. http://dx.doi.org/10.1016/j.atmosenv.2006.06.028

[9] Davidson, C.I., Santhanam, S., Fortmann, R.C. and Olson, M.P. (1985) Atmospheric Transport and Deposition of Trace Elements onto the Greenland Ice Sheet. Atmospheric Environment, 19, 2065-2081. http://dx.doi.org/10.1016/0004-6981(85)90115-5

[10] Dick, A.L. and Peel, D.A. (1985) Trace Elements in Antarctic Air and Snowfall. Annals of Glaciology, 7, 12-19.

[11] Junge, C.E. (1977) Processes Responsible for the Trace Content in the Precipitation. International Association of Hydrological Sciences Publication 118, (General Assembly of Grenoble 1975-Isotopes and Impurities in Snow and Ice), 63-77.

[12] Shaw, G.E. (1980) Optical, Chemical and Physical Properties of Aerosols over the Antarctic Ice Sheet. Atmospheric Environment, 14, 911-921. http://dx.doi.org/10.1016/0004-6981(80)90004-9

[13] Boutron, C. and Lorius, C. (1979) Trace Metals in Antarctic Snow since 1914. Nature, 277, 551-554. http://dx.doi.org/10.1038/277551a0

[14] Peel, D.A. and Wolff, E.W. (1982) Recent Variations in Heavy Metal Concentrations in Firn and Air from the Antarctica Peninsula. Annals of Glaciology, 3, 255-259.

[15] Boutron, C.F. and Patterson, C.C. (1983) The Occurrence of Lead in Antarctica Recent Snow, Firn Deposited over the Last Two Centuries and Prehistoric Ice. Geochimica et Cosmochimica Acta, 47, 1355-1368. http://dx.doi.org/10.1016/0016-7037(83)90294-6

[16] Wolff, E.W., Hall, J.S., Mulvaney, R., Pasteur, E.C., Wagenbach, D. and Legrand, M. (1998) Relationship between Chemistry of Air, Fresh Snow and Firn Cores for Aerosol Species in Coastal Antarctica. Journal of Geophysical Research, 103, 11057-11070. http://dx.doi.org/10.1029/97JD02613

[17] Sun, J., Qin, D., Mayewski, P.A., Dibb, J.E., Whitlow, S., Li, Z. and Yang, Q. (1998) Soluble Species in Aerosol and Snow and Their Relationship at Glacier 1, Tien Shan, China. Journal of Geophysical Research, 103, 28021-28028. http://dx.doi.org/10.1029/98JD01802

[18] Ming, J., Zhang, D., Kang, S. and Tian, W. (2007) Aerosol and Fresh Snow Chemistry in the East Rongbuk Glacier on the Northern Slope of Mt. Qomolangma (Everest). Journal of Geophysical Research, 112, Article ID: D15307. http://dx.doi.org/10.1029/2007JD008618

[19] Rahn, K.A. and McCaffrey, R.J. (1979) Compositional Differences between Arctic Aerosol and Snow. Nature, 280, 479-480. http://dx.doi.org/10.1038/280479a0 
[20] Davidson, C.I., Jaffrezo, J.-L., Mosher, B.W., Dibb, J.E., Borys, R.D., Bodhaine, B.A., Rasmussen, R.A., Boutron, C.F., Ducroz, F.M., Cacher, M., Ducret, J., Colin, J.-L., Heidam, N.Z., Kemp, K. and Hillamo, R. (1993) Chemical Constituents in the Air and Snow at Dye 3, Greenland-II. Analysis of Episodes in April 1989. Atmospheric Environment, 27A, 2723-2737. http://dx.doi.org/10.1016/0960-1686(93)90305-I

[21] Mosher, B.W., Winkler, P. and Jaffrezo, J.J. (1993) Seasonal Trends in Aerosol Chemistry at Dye 3, Greenland. Atmospheric Environment, Part A, 27, 2761-2772. http://dx.doi.org/10.1016/0960-1686(93)90308-L

[22] Jaffrezo, J.-L., Davidson, C.I., Legrand, M. and Dibb, J. (1994) Sulfate and MSA in the Air and Snow on the Greenland Ice Sheet. Journal of Geophysical Research, 99, 1241-1253. http://dx.doi.org/10.1029/93JD02913

[23] Dibb, J.E. and Jaffrezo, J.L. (1997) Air-Snow Investigations at Summit, Greenland, an Overview. Journal of Geophysical Research, 102, 26795-26807. http://dx.doi.org/10.1029/96JC02303

[24] Bergin, M.H., Davidson, C.I., Dibb, J.E., Jaffrezo, J.-L., Kuhns, H.D. and Pandis, S.N. (1995) A Simple Model to Estimate Atmospheric Concentrations of Irreversibly Deposited Aerosol Chemical Species Based on Snow Core Chemistry at Summit, Greenland. Geophysical Research Letters, 22, 3517-3520. http://dx.doi.org/10.1029/95GL03196

[25] Bergin, M.H., Pandis, S.N., Davidson, C.I., Jaffrezo, J.-L., Dibb, J.E., Russel, G. and Kuhns, H.D. (1996) Modelling of the Processing and Removal of Trace Gas and Aerosol Species by Arctic Radiation Fogs and Comparison with Measurements. Journal of Geophysical Research, 101, 14465-14478. http://dx.doi.org/10.1029/96JD00340

[26] Bales, R.C. and Choi, J. (1996) Conceptual Framework for Interpretation of Exchange Processes. In: Wolf, E. and Bales, R., Eds., Chemical Exchange between the Atmosphere and Polar Snow, Springer-Verlag, New York, 319-338. http://dx.doi.org/10.1007/978-3-642-61171-1_14

[27] Albert, M.R. (1996) Modelling Heat, Mass and Species Transport in Polar Firn. Annals of Glaciology, 23, $138-143$.

[28] Albert, M.R., Arons, E.M. and Davis, R.E. (1996) Firn Properties Affecting Gas Exchange at Summit, Greenland, Ventilations Possibilities. In: Wolf, E. and Bales, R., Eds., Chemical Exchange between the Atmosphere and Polar Snow, Springer-Verlag, New York, 561-565. http://dx.doi.org/10.1007/978-3-642-61171-1_24

[29] Borys, R.D., Hindman, E.E. and Demott, P.J. (1988) The Chemical Fractionation of Atmospheric Aerosol as a Result of Snow Crystal Formation and Growth. Journal of Atmospheric Chemistry, 7, 213-239. http://dx.doi.org/10.1007/BF00130931

[30] Pruppacher, H.R. and Klett, J.D. (1997) Microphysics of Clouds and Precipitation. 2nd Edition, Kluwer Academic, Dordrecht, $954 \mathrm{p}$.

[31] Ohtake, T. and Yogi, T. (1979) Winter Ice Crystals at the South Pole. Antarctic Journal of the United States, 14, 201203.

[32] Ohtake, T. and Inoue, M. (1980) Formation Mechanism of Ice Crystal Precipitation in the Antarctic Atmosphere. Proceedings of the VIII Conference on Internationale sur la physique des nuages, Clermont-Ferrand, 15-19 Juillet 1980, 221-224.

[33] Walden, V.P., Warren, S.G. and Tuttle, E. (2003) Atmospheric Ice Crystals over the Antarctic Plateau in Winter. Journal of Applied Meteorology, 42, 1391-1405. http://dx.doi.org/10.1175/1520-0450(2003)042<1391:AICOTA>2.0.CO;2

[34] Lawson, R.P., Baker, B.A., Zmarzly, P., O’Connor, D., Mo, Q., Gayet, J.-F. and Shcherbakov, V. (2006) Microphysical and Optical Properties of Atmospheric Ice Crystals at South Pole Station. Journal of Applied Meteorology and Climatology, 45, 1505-1524. http://dx.doi.org/10.1175/JAM2421.1

[35] Santachiara, G., Belosi, F. and Prodi, F. (2016) Ice Crystal Precipitation at Dome C Site (East Antarctica). Atmospheric Research, 167, 108-117. http://dx.doi.org/10.1016/j.atmosres.2015.08.006

[36] Warburton, J.A. and Linkletter, G.O. (1978) Atmospheric Processes and the Chemistry of Snow on the Ross Ice Shelf, Antarctica. Journal of Glaciology, 20, 149-162.

[37] Lachlan-Cope, T. (2010) Antarctic Clouds. Polar Research, 29, 150-158. http://dx.doi.org/10.1111/j.1751-8369.2010.00148.x

[38] Mossop, S.C., Cottis, R.E. and Bartlett, B.M. (2010) Ice Crystal Concentration in Cumulus and Strato-Cumulus Clouds. Quarterly Journal of the Royal Meteorological Society, 98, 105-123. http://dx.doi.org/10.1002/qj.49709841509

[39] Jayaweera, K.O.L.F. and Ohtake, T. (1973) Concentration of Ice Crystals in Arctic Stratus Clouds. Journal de Récherches Atmospheriques, 7, 199-207.

[40] Asuma, Y., Inoue, Y., Kikuchi, K., Kajikawa, M., Sato, N. and Hayasaka, T. (2000) Wintertime Precipitation Behaviour in the Western Canadian Arctic Region. Journal of Geophysical Research, 105, 14927-14939. http://dx.doi.org/10.1029/1999JD901124

[41] Douglas, T.A., Sturm, M., Simpson, W.R., Blum, J.D., Alvarez-Aviles, L., Keeler, G.J., Perovich, D.K., Biswas, A. and Johnson, K. (2008) Influence of Snow and Ice Crystal Formation and Accumulation on Mercury Deposition to the 
Arctic. Environmental Science and Technology, 42, 1542-1551. http://dx.doi.org/10.1021/es070502d

[42] Stuart, A.L. and Jacobson, M.Z. (2003) A Timescale Investigation of Volatile Chemical Retention during Hydrometeor Freezing, Nonrime Freezing and Dry Growth Riming without Spreading. Journal of Geophysical Research, 108, 4178. http://dx.doi.org/10.1029/2001jd001408

[43] Lamb, D. and Blumenstein, R. (1987) Measurements of the Entrapment of Sulfur Dioxide by Rime Ice. Atmospheric Environment, 21, 1765-1772. http://dx.doi.org/10.1016/0004-6981(87)90116-8

[44] Iribarne, J.V., Pyshnov, T. and Naik, B. (1990) The Effect of Freezing on the Composition of Supercooled DropletsII Retention of S(IV). Atmospheric Environment, 24, 389-395. http://dx.doi.org/10.1016/0960-1686(90)90119-8

[45] Santachiara, G., Vivarelli, F. and Prodi, F. (1992) $\mathrm{SO}_{2}$ Retention Coefficient during Freezing of Monodisperse Drops. Proceedings of the 11th International Conference on Clouds and Precipitation, Montreal, 17-21 August 1992, 916919.

[46] Iribarne, J.V. and Pyshnov, T. (1990) The Effect of Freezing on the Composition of Supercooled Droplets-I. Retention of $\mathrm{HCl}, \mathrm{HNO}_{3}, \mathrm{NH}_{3}$ and $\mathrm{H}_{2} \mathrm{O}_{2}$. Atmospheric Environment, 24A, 383-387. http://dx.doi.org/10.1016/0960-1686(90)90118-7

[47] Santachiara, G., Prodi, F. and Vivarelli, F. (1995) Scavenging of $\mathrm{SO}_{2}$ and $\mathrm{HCl}$ during Growth of Ice Crystals by Vapour Diffusion. Atmospheric Environment, 29, 983-987. http://dx.doi.org/10.1016/1352-2310(95)00023-R

[48] Voisin, D., Legrand, M. and Chaumerliac, N. (2000) Scavenging of Acidic Gases $\left(\mathrm{HCOOH}, \mathrm{CH}_{3} \mathrm{COOH}_{1} \mathrm{HNO}\right.$, $\mathrm{HCl}$ and $\mathrm{SO}_{2}$ ) and Ammonia in Mixed Liquid-Solid Water Clouds at the Puy de Dome Mountain (France). Journal of Geophysical Research, 105, 6817-6835. http://dx.doi.org/10.1029/1999JD900983

[49] Blohn, N., Diehl, K., Mitra, S.K. and Borrmann, S. (2011) Wind Tunnel Experiments on the Retention Coefficient of Trace Gases during Riming, Nitric Acid, Hydrochloric Acid, and Hydrogen Peroxide. Atmospheric Chemistry and Physics, 11, 11569-11579. http://dx.doi.org/10.5194/acp-11-11569-2011

[50] Snider, J.R. and Huang, J. (1998) Factors Influencing the Retention of Hydrogen Peroxide and Molecular Oxygen in Rime Ice. Journal of Geophysical Research, 103, 1405-1415. http://dx.doi.org/10.1029/97JD02847

[51] Snider, J.R., Montague, D.C. and Vali, G. (1992) Hydrogen Peroxide Retention in Rime Ice. Journal of Geophysical Research, 97, 7569-7578. http://dx.doi.org/10.1029/92JD00237

[52] Dominé, F. and Thibert, E. (1996) Mechanism of Incorporation of Trace Gases in Ice Grown from the Gas Phase. Geophysical Research Letters, 23, 3627-3630. http://dx.doi.org/10.1029/96GL03290

[53] Thibert, E. and Dominé, F. (1998) Thermodynamics and Kinetics of the Solid Solution of $\mathrm{HNO}_{3}$ in Ice. The Journal of Physical Chemistry B, 102, 4432-4439. http://dx.doi.org/10.1021/jp980569a

[54] Valdez, M.P., Dawson, G.A. and Bales, R.C. (1989) Sulfur Dioxide Incorporation into Ice Depositing from the Vapour. Journal of Geophysical Research, 94, 1095-1103. http://dx.doi.org/10.1029/JD094iD01p01095

[55] Mitra, S.K., Barth, S. and Pruppacher, H.R. (1990) A Laboratory Study on the Scavenging of $\mathrm{SO}_{2}$ by Snow Crystals. Atmospheric Environment, 24A, 2307-2312. http://dx.doi.org/10.1016/0960-1686(90)90324-g

[56] Diehl, K., Mitra, S.K. and Pruppacher, H.R. (1995) A Laboratory Study of the Uptake of $\mathrm{HNO}_{3}$ and $\mathrm{HCl}$ Vapour by Snow Crystals and Ice Spheres at Temperature between 0 and $-40^{\circ} \mathrm{C}$. Atmospheric Environment, 29, 975-981. http://dx.doi.org/10.1016/1352-2310(95)00022-Q

[57] Santachiara, G., Prodi, F., Udisti, R. and Prodi, A. (1998) Scavenging of $\mathrm{SO}_{2}$ and $\mathrm{NH}_{3}$ during Growth of Ice. Atmospheric Environment, 47-48, 209-217. http://dx.doi.org/10.1016/s0169-8095(97)00087-2

[58] Ullerstam, M. and Abbatt, J.P.D. (2005) Burial of Gas-Phase $\mathrm{HNO}_{3}$ by Growing Ice Surfaces under Tropospheric Conditions. Physical Chemistry Chemical Physics, 7, 3596-3600. http://dx.doi.org/10.1039/b507797d

[59] Hoog, I., Mitra, S.K. and Diehl, K. (2007) Laboratory Studies about the Interaction of Ammonia with Ice Crystals at Temperatures between 0 and $-20^{\circ} \mathrm{C}$. Journal of Atmospheric Chemistry, 57, 73-84. http://dx.doi.org/10.1007/s10874-007-9063-0

[60] McNeill, V.F., Loerting, T., Geiger, F.M., Trout, B.L. and Molina, M.J. (2006) Hydrogen Chloride-Induced Surface Disordering on Ice. Proceedings of the National Academy of Sciences of the United States of America, 103, 9422-9427. http://dx.doi.org/10.1073/pnas.0603494103

[61] Abbatt, J.P.D., Bartels-Rausch, T., Ullerstam, M. and Ye, T.J. (2008) Uptake of Acetone, Ethanol and Benzene to Snow and Ice, Effects of Surface Area and Temperature. Environmental Research Letters, 3, Article ID: 045008.

[62] Fletcher, N.H. (1968) Surface Structure of Water and Ice. II. A Revised Model. Philosophical Magazine, 18, 12871300. http://dx.doi.org/10.1080/14786436808227758

[63] Golecki, I. and Jaccard, C. (1978) Intrinsic Surface Disorder in Ice near the Melting Point. Journal of Physics C: Solid State Physics, 11, 4229-4237. http://dx.doi.org/10.1088/0022-3719/11/20/018

[64] Gubler, H. (1982) Strength of Bonds between Ice Grains after Short Contact Times. Journal of Glaciology, 28, 457- 
473.

[65] Stefan, J. (1881) Über die Verdampfung aus einem kreisförming oder elliptisch begrenzten Becken. Annalen der Physik, 253, 550-560.

[66] Kulmala, M. and Vesala, T. (1991) Condensation in the Continuum Regime. Journal of Aerosol Science, 22, 337-346. http://dx.doi.org/10.1016/S0021-8502(05)80011-4

[67] Listowski, C., Määttänen, A., Riipinen, I., Montmessin, F. and Lefèvre, F. (2013) Near-Pure Vapour Condensation in the Martian Atmosphere, $\mathrm{CO}_{2}$ Ice Crystal Growth. Journal of Geophysical Research Planets, 118, 2153-2171.

[68] Legrand, M., Wolff, E. and Wagenbach, D. (1999) Antarctic Aerosol and Snowfall Chemistry, Implications for Deep Antarctic Ice Core Chemistry. Annals of Glaciology, 29, 66-72. http://dx.doi.org/10.3189/172756499781821094

[69] Abbatt, J.P.D. (1997) Interactions of $\mathrm{HNO}_{3}$ with Water-Ice Surfaces at Temperatures of the Free Troposphere. Geophysical Research Letters, 24, 1479-1482. http://dx.doi.org/10.1029/97GL01403

[70] Hynes, R.G., Fernandez, M.A. and Cox, R.A. (2002) Uptake of $\mathrm{HNO}_{3}$ on Water-Ice and Coadsorption of $\mathrm{HNO}_{3}$ and $\mathrm{HCl}$ in the Temperature Range 210-235 K. Journal of Geophysical Research, 107, 4797. http://dx.doi.org/10.1029/2001JD001557

[71] Hudson, P.K., Shilling, J.E., Tolbert, M.A. and Toon, O.B. (2002) Uptake of Nitric Acid at Tropospheric Temperatures, Implications for Cirrus Clouds. The Journal of Physical Chemistry A, 106, 9874-9882. http://dx.doi.org/10.1021/jp020508j

[72] Popp, P.J., Marcy, T.P., Watts, L.A., et al. (2007) Condensed-Phase Nitric Acid in a Tropical Subvisible Cirrus Cloud. Geophysical Research Letters, 34, Article ID: L24812. http://dx.doi.org/10.1029/2007gl031832

[73] Kärcher, B., Abbatt, J.P.D., Cox, R.A., Popp, P.J. and Voight, C. (2009) Trapping of Trace Gases by Growing Ice Surfaces including Surface-Saturated Adsorption. Journal of Geophysical Research, 114, Article ID: D13306. http://dx.doi.org/10.1029/2009jd011857

[74] Zondlo, M.A., Barone, S.B. and Tolbert, M.A. (1997) Uptake of $\mathrm{HNO}_{3}$ on Ice under Upper Tropospheric Conditions. Geophysical Research Letters, 24, 1391-1394. http://dx.doi.org/10.1029/97GL01287

[75] Coutch, T.L., Summer, A.L., Dassau, T.M., Shepson, P.B. and Honrath, R.E. (2000) An Investigation of the Interaction of Carbonyl Compounds with the Snowpack. Geophysical Research Letters, 27, 2241-2244. http://dx.doi.org/10.1029/1999GL011288

[76] Huebert, B.J., Fehsenfeld, F.C., Norton, R.B. and Albritton, D. (1983) The Scavenging of Nitric Acid by Snow. In: Precipitation Scavenging, Dry Deposition and Resuspension, Elsevier, Amsterdam, 293-302.

[77] Shrestha, A.B., Wake, C.P. and Dibb, J.E. (1997) Chemical Composition of Aerosol and Snow in the High Himalaya during the Summer Monsoon Season. Atmospheric Environment, 31, 2815-2826. http://dx.doi.org/10.1016/S1352-2310(97)00047-2

[78] Schwikowski, M., Baltensperger, U., Gäggeler, H.W. and Poulida, O. (1998) Scavenging of Atmospheric Constituents in Mixed Phase Clouds at the High-Alpine Site Jungfraujoch: Part III, Quantification of the Removal of Chemical Species. Atmospheric Environment, 32, 4001-4010. http://dx.doi.org/10.1016/S1352-2310(98)00050-8

[79] Ehrman, S.H., Schwikowski, M., Baltensperger, U. and Gäggeler, H.W. (2001) Sampling and Chemical Analysis of Ice Crystals as a Function of Size. Atmospheric Environment, 35, 5371-5376. http://dx.doi.org/10.1016/S1352-2310(01)00294-1

[80] Ianniello, A., Beine, H.J., Sparapani, R., Di Bari, F., Allegrini, I. and Fuentes, J.D. (2002 Denuder Measurements of Gas and Aerosol Species above Snow Surface at Alert 2000. Atmospheric Environment, 36, 5299-5309. http://dx.doi.org/10.1016/S1352-2310(02)00646-5

[81] Beine, H.J., Dominé, F., Ianniello, A., Nardino, M., Allegrini, I., Teinilä, K. and Hillamo, R. (2003) Fluxes of Nitrate between Snow Surfaces and the Atmosphere in the European High Arctic. Atmospheric Chemistry and Physics, 3, 335346. http://dx.doi.org/10.5194/acp-3-335-2003

[82] Puxbaum, H. and Tscherwenka, W. (1998) Relationships of Major Ions in Snow Fall and Rime at Sonnblick Observatory (SBO, $3106 \mathrm{~m}$ ) and Implications for Scavenging Processes in Mixed Clouds. Atmospheric Environment, 32, 40114020. http://dx.doi.org/10.1016/S1352-2310(98)00244-1

[83] Mitchell, D.L. and Lamb, D. (1989) Influence of Riming on the Chemical Composition of Snow in Winter Orographic Storms. Journal of Geophysical Research, 94, 14831-14840. http://dx.doi.org/10.1029/JD094iD12p14831

[84] Mitchell, D.L. and Borys, R.D. (1991) A Field Instrument for Examining In-Cloud Scavenging Mechanisms by Snow. Proceedings of the Fifth International Conference on Precipitation Scavenging and Atmosphere-Surface Exchange Processes, Richland, 15-19 July 1991, 239-253.

[85] Duncan, L.C. (1992) Chemistry of Rime and Snow Collected at a Site in the Central Washington Cascades. Environmental Science and Technology, 26, 61-66. http://dx.doi.org/10.1021/es00025a003 
[86] Baltensperger, U., Schwikowski, M., Gäggeler, H.W., Jost, D.T., Beer, J., Siegenthaler, U., Wagenbach, D., Hofmann, H.J. and Synal, H.A. (1993) Transfer of Atmospheric Constituents into an Alpine Snow Field. Atmospheric Environment, 27A, 1881-1890. http://dx.doi.org/10.1016/0960-1686(93)90293-8

[87] Albert, M.R. and Shultz, E.F. (2002) Snow and Firn Properties and Air-Snow Transport Processes at Summit, Greenland. Atmospheric Environment, 36, 2789-2797. http://dx.doi.org/10.1016/S1352-2310(02)00119-X

[88] Tranter, M. and Jones, H.G. (2001) The Chemistry of Snow, Processes and Nutrient Cycling. In: Jones, H.G., Pomeroy, J.W., Walker, D.A. and Hoham, R.W., Eds., Snow Ecology, Cambridge University Press, Cambridge, 127-167.

[89] Silvente, E. and Legrand, M. (1993) Ammonium to Sulphate Ratio in Aerosol and Snow of Greenland and Antarctic Regions. Geophysical Research Letters, 20, 687-690. http://dx.doi.org/10.1029/93GL00982

[90] Pourchet, M., Pinglot, F. and Lorius, C. (1983) Some Meteorological Applications of Radioactive Fallout Measurements in Antarctic Snow. Journal of Geophysical Research Ocean, 88, 6013-6020. http://dx.doi.org/10.1029/JC088iC10p06013

[91] Legrand, M. (1987) Chemistry of Antarctic Snow and Ice. Journal of Physics, 48, C1/77-C1/86. http://dx.doi.org/10.1051/jphyscol:1987111

[92] Gjessing, Y. (1984) Marine and Non-Marine Contribution to the Chemical Composition of Snow at the Riiser-Larseninen Ice Shelf in Antarctica. Atmospheric Environment, 18, 825-883. http://dx.doi.org/10.1016/0004-6981(84)90267-1

[93] Sommerfeld, R.A. and Lamb, D. (1986) Preliminary Measurements of $\mathrm{SO}_{2}$ Adsorbed on Ice. Geophysical Research Letters, 13, 349-351. http://dx.doi.org/10.1029/GL013i004p00349

[94] Johannson, C. and Granat, L. (1986) An Experimental Study of the Dry Deposition of Gaseous Nitric Acid to Snow. Atmospheric Environment, 20, 1165-1170. http://dx.doi.org/10.1016/0004-6981(86)90150-2

[95] Sigg, A., Staffelbach, T. and Neftel, A. (1992) Gas Phase Measurements of Hydrogen Peroxide in Greenland and Their Meaning for the Interpretation of $\mathrm{H}_{2} \mathrm{O}_{2}$ Records in Ice Cores. Journal of Atmospheric Chemistry, 14, 223-232. http://dx.doi.org/10.1007/BF00115235

[96] Conklin, M.H. and Bales, R.C. (1993) $\mathrm{SO}_{2}$ Uptake on Ice Spheres, Liquid Nature of the Ice-Air Interface. Journal of Geophysical Research, 98, 16851-16855. http://dx.doi.org/10.1029/93JD01207

[97] Ullerstam, M., Thornberry, T. and Abbatt, J.P.D. (2005) Uptake of Gas-Phase Nitric Acid to Ice at Low Partial Pressure, Evidence for Unsaturated Surface Coverage. Faraday Discussion, 130, 211-226. http://dx.doi.org/10.1039/b417418f

[98] Ginot, P., Kull, C., Schwikowski, M., Schotterer, U. and Gäggeler, H.W. (2001) Effects of Postdepositional Processes on Snow Composition of a Subtropical Glacier (Cerro Tapado, Chilean Andes). Journal of Geophysical Research, 106, 32375-32386. http://dx.doi.org/10.1029/2000JD000071

[99] Gow, A.J. (1964) On the Accumulation and Seasonal Stratification of Snow at the South Pole. Journal of Glaciology, 5, 467-477.

[100] Prodi, F. and Levi, L. (1980) Aging of Accreted Ice. Journal of the Atmospheric Sciences, 37, 1375-1384. http://dx.doi.org/10.1175/1520-0469(1980)037<1375:AOAI >2.0.CO;2

[101] Colbeck, S.C. (1982) An Overview of Seasonal Snow Metamorphism. Reviews of Geophysics and Space Physics, 20, 45-61. http://dx.doi.org/10.1029/RG020i001p00045

[102] Colbeck, S.C. (1997) A Review of Sintering in Seasonal Snow Cover. CRREL Report 97-10, 11 p.

[103] Hutterli, M.A., Röthlinsberger, R. and Bales, R.C. (1999) Atmosphere-to-Snow-to-Firn Transfer Studies of HCHO at Summit, Greenland. Geophysical Research Letters, 26, 1691-1694. http://dx.doi.org/10.1029/1999GL900327

[104] Dominé, F. and Shepson, P.B. (2002) Air-Snow Interactions and Atmospheric Chemistry. Science, 297, $1506-1510$. http://dx.doi.org/10.1126/science.1074610

[105] Grannas, A.M., Jones, A.E., Dibb, J., et al. (2007) An Overview of Snow Photochemistry, Evidence, Mechanisms and Impacts. Atmospheric Chemistry and Physics, 7, 4329-4373. http://dx.doi.org/10.5194/acp-7-4329-2007

[106] Hamer, P.D., Shallcross, D.E., Yabushita, A., Kawasaki, M., Marécal, V. and Boxe, C.S. (2014) Investigating the Photo-Oxidative and Heterogeneous Chemical Production of HCHO at the South Pole, Antarctica. Environmental Chemistry, 11, 459-471. http://dx.doi.org/10.1071/EN13227

[107] Bartel-Rausch, T., Jacobi, H.-W., Kahan, T.F., et al. (2014) A Review of Air-Ice Chemical and Physical Interactions (AICI), Liquids, Quasi-Liquids, and Solids in Snow. Atmospheric Chemistry and Physics, 14, 1587-1633. http://dx.doi.org/10.5194/acp-14-1587-2014

[108] Dibb, J.E., Talbot, R.W., Munger, J.W., Jacob, D.J. and Fan, S.-M. (1998) Air-Snow Exchange of $\mathrm{HNO}_{3}$ and $\mathrm{NO}_{\mathrm{y}}$ at Summit, Greenland. Journal of Geophysical Research, 103, 3475-3486. http://dx.doi.org/10.1029/97JD03132

[109] Honrath, R.E., Peterson, M.C., Guo, S., Dibb, J.E., Shepson, P.B. and Campbell, B. (1999) Evidence of NO Produc- $^{-}$ 
tion within or upon Ice Particles in the Greenland Snowpack. Geophysical Research Letters, 26, 695-698. http://dx.doi.org/10.1029/1999GL900077

[110] Weller, R., Minikin, A., König-Langlo, G., Schrems, O., Jones, A.E., Wolff, E.W. and Anderson, P.S. (1999) Investigating Possible Causes of the Observed Diurnal Variability in Antarctic $\mathrm{NO}_{\mathrm{y}}$. Geophysical Research Letters, 26, 28532856. http://dx.doi.org/10.1029/1999GL900608

[111] Erbland, J., Vicars, W.C., Savarino, J., Morin, S., Frey, M.M., Frosini, D., Vince, E. and Martins, J.M.F. (2013) AirSnow Transfer of Nitrate on the East Antarctic Plateau-Part 1, Isotopic Evidence for a Photolytically Driven Dynamic Equilibrium in Summer. Atmospheric Chemistry and Physics, 13, 6403-6419. http://dx.doi.org/10.5194/acp-13-6403-2013

[112] Neubauer, J. and Heumann, K.G. (1988) Nitrate Trace Determinations in Snow and Firn Core Samples of Ice Shelves at the Weddel Sea, Antarctica. Atmospheric Environment, 22, 537-545. http://dx.doi.org/10.1016/0004-6981(88)90197-7

[113] Neubauer, J. and Heumann, K.G. (1988) Determination of Nitrate at the ng/g Level in Antarctic Snow Samples with Ion Chromatography and Isotope Dilution Mass Spectrometry. Fresenious Zeitschrift für Analytische Chemie, 331, 170-173. http://dx.doi.org/10.1007/BF01105161

[114] Champollion, N., Picard, G., Arnaud, L., Lefebvre, E. and Fily, M. (2013) Hoar Crystal Development and Disappearance at Dome C, Antarctica, Observation by Near-Infrared Photography and Passive Microwave Satellite. The Cryosphere, 7, 1247-1262. http://dx.doi.org/10.5194/tc-7-1247-2013

[115] Linkleter, G.O. and Warburton, J.A. (1976) A Note on the Contribution of Rime and Surface Hoar to the Accumulation on the Ross Ice Shelf, Antarctica. Journal of Glaciology, 17, 351-354.

[116] Wolff, E.W., Jones, A.E., Bauguitte, S.J.B. and Salmon, R.A. (2008) The Interpretation of Spikes and Trends in Concentration of Nitrate in Polar Ice Cores, Based on Evidence from Snow and Atmospheric Measurements. Atmospheric Chemistry and Physics, 8, 5627-5634. http://dx.doi.org/10.5194/acp-8-5627-2008

[117] Mayewski, P.A. and Legrand, M.R. (1990) Recent Increase in Nitrate Concentration of Antarctic Snow. Nature, 346, 258-260. http://dx.doi.org/10.1038/346258a0

[118] Wagnon, P., Delmas, R.J. and Legrand, M. (1999) Loss of Volatile Acid Species from Upper Firn Layers at Vostok, Antarctica. Journal of Geophysical Research, 104, 3423-3431.

[119] Blunier, T., Floch, G.L., Jacobi, H.-W. and Quansah, E. (2005) Isotopic View on Nitrate Loss in Antarctic Surface Snow. Geophysical Research Letters, 32, Article ID: L13501. http://dx.doi.org/10.1029/2005gl023011

[120] Traversi, R., Becagli, S., Castellano, E., Cerri, O., Morganti, A., Severi, M. and Udisti, R. (2009) Study of Dome C Site (East Antarctica) Variability by Comparing Chemical Stratigraphies. Microchemical Journal, 92, 7-14. http://dx.doi.org/10.1016/j.microc.2008.08.007

[121] Frey, M.M., Savarino, J., Morin, S., Erbland, J. and Martins, J.M.F. (2009) Photolysis Imprint in the Nitrate Stable Isotope Signal in Snow and Atmosphere of East Antarctica and Implications for Reactive Nitrogen Cycling. Atmospheric Chemistry and Physics, 9, 8681-8696. http://dx.doi.org/10.5194/acp-9-8681-2009

[122] Röthlisberger, R., Hutterli, M.A., Sommer, S., Wolff, E.W. and Mulvaney, R. (2000) Factors Controlling Nitrate in Ice Cores, Evidence from the Dome C Deep Ice Core. Journal of Geophysical Research, 105, 20565-20572. http://dx.doi.org/10.1029/2000JD900264

[123] Burkhar, J.F., Hutterli, M., Bales, R.C. and McConnel, J.R. (2004) Seasonal Accumulation Timing and Preservation of Nitrate in Firn at Summit, Greenland. Journal of Geophysical Research, 109, Article ID: D19302. http://dx.doi.org/10.1029/2004JD004658

[124] Hastings, M.G., Jarvis, J.C. and Steig, E.J. (2009) Anthropogenic Impacts on Nitrogen Isotopes of Ice-Core Nitrate. Science, 324, 1288. http://dx.doi.org/10.1126/science.1170510

[125] Berhanu, T.A., Meusinger, C., Erbland, J., Jost, R., Bhattacharya, S.K., Johnson, M.S. and Savarino, J. (2014) Laboratory Study of Nitrate Photolysis in Antarctic Snow. II. Isotopic Effects and Wavelength Dependence. The Journal of Chemical Physics, 140, Article ID: 244306. http://dx.doi.org/10.1063/1.4882899

[126] Dubowski, Y., Colussi, A.J. and Hoffmann, M.R. (2001) Nitrogen Dioxide Release in the 302 nm Band Photolysis of Spray-Frozen Aqueous Nitrate Solutions. Atmospheric Implications. The Journal of Physical Chemistry A, 105, 49284932. http://dx.doi.org/10.1021/jp0042009

[127] Chu, L. and Anastasio, C. (2003) Quantum Yields of Hydroxyl Radicals and Nitrogen Dioxide from the Photolysis of Nitrate on Ice. The Journal of Physical Chemistry A, 107, 9594-9602. http://dx.doi.org/10.1021/jp0349132 